\title{
KOMPETENSI TENAGA PENDIDIK PENDIDIKAN NONFORMAL DALAM MEMBANGUN KEMANDIRIAN WARGA BELAJAR
}

\author{
Mustafa Kamil
}

\begin{abstract}
Non-formal education quality will be reached if it is developed by professional and competent nonformal education personnel. Two factors needed by non-formal education personnel in strengthening their professionalism and competencies are the skills and abilities in developing and improving learners' autonomy. This article discusses (1) the definitions of non-formal learners' autonomy, (2) the roles and tasks of non-formal education personel in performing non-formal learners' autonomy, and (3) a set of competencies and skill of non-formal education personnel in performing non-formal learners' autonomy. In conclusion some suggestions to improve the quality of non-formal education personnel presented.
\end{abstract}

Key words: education personel, competency, professionalism and autonomy.

\section{PENDAHULUAN}

Profesi pendidik pendidikan nonformal sampai saat ini belum mendapatkan porsi yang layak dalam penyelenggaraan pendidikan di Indonesia. Begitu pula dengan lahirnya Undang-Undang tentang Guru dan Dosen, yang melengkapi dan menguatkan semangat perbaikan mutu pendidikan nasional, dan sebelumnya juga sudah tertuang dalam UU Nomor 20/2003 tentang Sistem Pendidikan Nasional, belum memberikan kecerahan bagi keberadaan tenaga pendidik pendidikan nonformal. Pada saat yang sama, Peraturan Menteri Pendidikan Nasional tentang kompetensi pendidik pendidikan nonformal belum dapat dilahirkan sampai saat ini. Namun demikian, melihat jumlah tenaga pendidik pendidikan nonformal yang begitu banyak, peran dan tugas-tugas yang dibebankan kepadanya begitu berat, serta perkembangan pendidikan nonformal yang semakin maju dan mendapatkan tempat di masyarakat, sudah seharusnya tenaga pendidik pendidikan nonformal mendapatkan posisi yang sejajar dengan tenaga pendidik lainnya dalam membangun kualitas (mutu) pendidikan, khususnya pendidikan nonformal.

Untuk itulah tulisan ini akan membahas tentang kompetensi pendidik pendidikan nonformal yang berkaitan dengan kemampuan dan keterampilan dalam menumbuhkan dan mengembangkan kemandirian warga belajar. Menumbuhkan kemandirian warga belajar merupakan sisi paling mendasar (core) dalam pengembangan kurikulum dan pembelajaran pendidikan nonformal. Oleh karena itu kemampuan menumbuhkan dan mengembangkan kemandirian warga belajar merupakan hal yang esensial dibutuhkan tenaga pendidik pendidikan nonformal pembahasan akan dibagi dalam beberapa bagian, yakni: 1) pengertian kemandirian warga belajar, 2) peran dan tugas tenaga pendidik pendidikan nonformal dalam membangun kemandirian warga belajar, 3) kompetensi yang perlu dimiliki tenaga pendidik pendidikan nonformal dalam membangun kemandirian warga belajar, dan 4) kesimpulan.

\section{PEMBAHASAN}

\section{Pengertian Kemandirian Warga Belajar}

Nilai-nilai kemandirian yang dimiliki individu akan menjadi sempurna apabila didukung oleh sifat-sifat kemandirian yang meliputi mandiri psikososial, kultural dan ekonomi, disiplin prakarsa dan wirausaha, kepemimpinan, dan orientasi prestasi dalam

\footnotetext{
* Dosen Universitas Pendidikan Indonesia
}

persaingan. Kerja, kemandirian muncul seiring dengan berkembangnya orientasi kerja, yang mengarah pada sikap wirausaha/wiraswasta. Perilaku mandiri merupakan fundamen dasar bagi seseorang dalam meningkatkan kualitas kerja (pekerjaannya). Suharsono Sagir menyatakan bahwa mandiri, menciptakan kerja untuk diri sendiri, maupun berkembang menjadi wiraswasta yang mampu menciptakan lapangan kerja bagi orang lain ataupun mampu menjadi cendekiawan, 
manusia yang berkreasi, inovatif, melalui ide-idenya atau hasil penemuannya, menjadikan masyarakat lebih baik; baik dalam bentuk inovasi teknologi, ataupun inovasi ilmu yang mampu mengembangkan ilmu lebih maju, sebagai upaya preventif maupun repressif untuk kelangsungan hidup sumberdaya manusia. (Suharsono Sagir, 1986).

Jiwa mandiri tumbuh dan berkembang seiring dengan tumbuhnya konsep wiraswasta atau dikenal istilah lain, yakni wirausaha dan kewirausahaan, juga istilah lain disebut dengan makarya. Seorang wiraswastawan harus memiliki jiwa mandiri atau kemandirian. Wasty Soemanto menyebutkan dalam tulisannya bahwa wiraswasta adalah keberanian, keutamaan serta kepercayaan dalam memenuhi kebutuhan serta memecahkan permasalahan hidup dengan ketekunan yang ada dalam diri sendiri. Begitu pula yang diungkapkan Meredith (1989), jiwa entrepreneurship (mandiri) ditentukan oleh tiga komponen utama yang ada dalam diri seseorang, yakni kemauan, ketekunan dan keuletan (Wasty Soemanto, 1976). Kemandirian sebagai kepribadian atau sikap mental yang harus dimiliki oleh setiap orang perlu dikembangkan agar tumbuh menyatu dalam setiap gerak kehidupan manusia. Asumsi tersebut menunjukkan bahwa kemandirian dapat menentukan sikap dan perilaku seseorang menuju ke arah wiraswastawan.

Pada dunia ekonomi, jiwa mandiri (kemandirian) sudah dikenal sejak tahun 1755 oleh Cantillon dikenal dengan istilah 0 . Kemudian, dikembangkan lagi setengah abad kemudian oleh Schumpeter tahun 1911 dan oleh Sombart tahun 1929. Pada pertengahan abad itulah entrepreneur menjadi cikal bakal bagi perkembangannya di dunia ekonomi modern. (Daoed Yoesoef, 1976)

Pada dunia pembangunan masyarakat, kemandirian sudah dikenal sejak PBB memberikan batasan tentang pengertian pembangunan masyarakat (Community Development). Pada definisi tersebut disebutkan bahwa: ...the participation of the people themselves in efforts to improve their level of living with as much reliance as possible on their own initiative, and the provision of technical and other services in ways which encourage initiative, self-help and mutual help and make these more effective - (UN, 1956). àtidak ada di daftar pustaka

Mengacu pada batasan tersebut, kemandirian memiliki nilai lain yang tidak hanya sekadar menjiwai konsep wiraswasta yang lebih mengarah pada nilainilai ekonomi (benefit), namun pada definisi tersebut terkandung pula nilai sosial dan nilai budaya dengan kandungan utamanya selain mampu menolong dirinya sendiri, mampu menolong orang lain dalam bentuk gotong royong dan partisipasi. Sehubungan juga dengan itu, konsep kemandirian yang menjiwai nilai-nilai wiraswasta sebenarnya hanya sebagian kecil saja. Secara lebih luas, kemandirian tidak hanya untuk itu, akan tetapi berlaku bagi setiap gerak langkah kehidupan manusia.

Pada konteks pendidikan nonformal, kemandirian merupakan tolok ukur utama dalam setiap pengembangan program-programnya. Oleh karena itu, kurikulum program pembelajaran pendidikan nonformal, secara lebih khusus memiliki inti dasar yang mengacu pada menumbuhkan dan mengembangkan nilai-nilai kemandirian bagi setiap sasaran didiknya (warga belajar). Tanpa tujuan itu, setiap program pembelajaran pendidikan nonformal menjadi tidak bermakna dan sama saja dengan program pembelajaran tanpa arah. Asumsi ini merupakan batasan khusus yang mampu membedakan program pendidikan nonformal dengan model program pendidikan lainnya.

Pengembangan program pendidikan nonformal yang mengacu pada kemandirian sasaran didik merupakan tekanan khusus yang seringkali menjadi patokan dan prinsip dasarnya. Oleh karena itu, program pendidikan nonformal nampak lebih fleksibel. Hal ini terlihat dari tujuan yang ingin dicapai selalu disesuaikan dengan tuntutan kebutuhan yang berkembang pada sasarannya (warga belajar). Di samping itu, program pendidikan nonformal selain fleksibel, cenderung berkaitan erat dengan lapangan pekerjaan peserta didik. Dengan berbagai keterampilan dan sikap yang dibina dalam pendidikan nonformal, sasaran didik (warga belajar) diharapkan mempunyai sejumlah kemampuan yang kemudian hari dapat dijadikan modal untuk mengembangkan usahanya secara mandiri dan memperoleh keuntungan yang lebih baik, keuntungan dalam aspek ekonomi, sosial, maupun budaya.

Prinsip tersebut memiliki asumsi bahwa pendidikan nonformal dalam pengembangan programnya selalu memperhitungkan potensi dan otonomi yang dimiliki warga belajar. Hal itu menjadi landasan utama bagi setiap perencanaan dan pengembangan program pendidikan nonformal. Secara filosofis, pandangan tersebut sejalan dengan konsep humanistik. Alasan utamanya, humanistik merupakan salah satu aliran filsafat yang memandang bahwa manusia memiliki potensi dan otonomi dalam kehidupannya.

Sejalan dengan konteks ketenagakerjaan, tujuan pendidikan nonformal semakin jelas dan terfokus terutama dilihat dari klasifikasi kegiatannya, yaitu : 1) 
mengembangkan kemampuan, pengetahuan dan keterampilan tenaga kerja yang sudah dan sedang bekerja; 2) menyiapkan warga belajar, terutama warga belajar dikalangan generasi muda yang akan memasuki lapangan kerja; dan 3) meningkatkan pengetahuan, keterampilan serta pemahaman warga belajar tentang perubahan kemajuan dalam dunia kerja. (C.S. Brembeck dan T.J. Thomson, 1973). à belum ada pada daftar pustaka

Tujuan dan kajian filosofis humanistik tersebut memberikan kejelasan bahwa tujuan pendidikan nonformal adalah mengembangkan seoptimal mungkin kemampuan dan potensi sasaran didik pendidikan nonformal, sehingga pada akhirnya dapat meningkatkan dan menolong dirinya sendiri. Di samping itu, peserta didik diharapkan pula dapat membangun lingkungan, masyarakat, dan lebih luas lagi dapat berperan secara aktif dalam membangun bangsa dan negaranya. Morris (1979) secara tegas memberikan kesimpulan bahwa tujuan pendidikan nonformal adalah membimbing masyarakat agar mampu membimbing dirinya sendiri. Djudju Sudjana (1992), menyebutkan bahwa tugas pokok pendidikan nonformal adalah membelajarkan warga belajar, dengan tujuan agar warga belajar memiliki atau mengembangkan nilai-nilai, sikap, pengetahuan dan keterampilan yang diperlukan dalam memenuhi kebutuhan individu, masyarakat, lembaga, dan pembangunan bangsa menuju masa depan yang lebih baik.

Dalam hal peningkatan kemandirian warga belajar, pendidikan nonformal dengan prinsip dasar bahwa belajar harus menjadi suatu kegemaran dan menjadi kebutuhan, menciptakan belajar aktif dengan sendirinya (self active learning propelling?). Pada konteks itu, keinginan dan kebutuhan belajar muncul dari dalam diri sendiri (internal motivation) dan bukan didorong atau dianjurkan orang lain (external motivation). Sikap tersebut muncul apabila warga belajar merasa bahwa dengan pembelajaran, mereka merasa mendapat pengetahuan, nilai tambah bagi pengembangan diri, serta dapat mengatasi permasalahan yang dihadapi dirinya dan orang lain. Di samping itu, dengan pembelajaran warga belajar juga merasakan adanya peningkatan kemampuan dalam berpikir, memperluas wawasan, meningkatkan pemahaman, keterampilan, kualitas hidup dan kehidupannya serta kariernya. Belajar dirasakan memberi makna yang jelas dalam dan bagi hidup dan kehidupan warga belajar, serta memudahkan untuk melakukan suatu karya, memudahkan bagi kehidupannya. Demikian, belajar dapat menyebabkan terjadinya proses transformasi kearah kemandirian.

\section{Kompetensi Tenaga Pendidik Pendidikan Nonformal dalam Membangun Kemandirian Warga Belajar}

Salah satu sumber belajar yang paling utama dalam pendidikan nonformal adalah "guru" pendidikan nonformal. Namun, kata guru seringkali tidak dipergunakan baik dalam konsepsi maupun praktika pembelajaran pendidikan nonformal. Guru biasanya digunakan dalam pendidikan formal atau sekolah. Dalam pendidikan nonformal, seringkali istilah guru diganti dengan tutor, fasilitator, atau pelatih.

Pada penyelenggaraan program pendidikan nonformal, tutor dan fasilitator seringkali bertindak sebagai guru pendidikan nonformal, baik dalam program kesetaraan (paket A, paket B dan Paket C) maupun dalam berbagai kegiatan pendidikan nonformal lainnya. Tutor dan fasilitator memiliki fungsi dan peran yang berbeda, akan tetapi fasilitator bisa juga bertindak sebagai tutor atau sebaliknya.

Tutor dalam pendidikan nonformal adalah orang yang profesional (memiliki kompetensi, kemampuan, dan keterampilan) dalam mengelola proses pembelajaran pendidikan nonformal. Tugas-tugas yang dibebankan kepadanya antara lain: (1) memahami dan mengembangkan kurikulum pembelajaran, (2) merencanakan dan menyiapkan bahan pembelajaran (materi), (3) memformulasi proses pembelajaran, (4) mengelola administrasi pembelajaran, (5) mengelola proses pembelajaran, (6) memotivasi warga belajar, (7) menggali sumber-sumber pembelajaran, (8) mengaktifkan warga belajar dalam proses pembelajaran, dan (9) mengevaluasi dan membuat laporan pembelajaran.

Adapun yang dimaksud dengan fasilitator adalah orang yang professional dalam memfasilitasi program pendidikan nonformal. Tugas-tugasnya antara lain: (1) menyiapkan rencana program, (2) mengelola program, (3) menyiapkan sumber-sumber pembelajaran, (4) melakukan monitoring dan evaluasi 
program, (5) memelihara kelangsungan program pendidikan nonformal, (6) mensosialisasikan program ke masyarakat, dan (7) membangun kemitraan (Kominkan, 2006).

Jika ditelaah dalam makna yang lebih mendasar, peran tutor dan fasilitator dalam pendidikan nonformal tidak hanya terampil dan mampu dalam mengembangkan dan melaksanakan kurikulum, mengelola program pendidikan nonformal dan dalam mengelola proses pembelajaran, akan tetapi yang paling utama adalah profesional dalam menyiapkan warga belajar menjadi manusia-manusia yang memiliki masa depan yang jelas. Ketika proses pembelajaran berlangsung atau ketika materi pembelajaran disampaikan, para tutor dan fasilitator memahami, makna proses dan materi pembelajaran tersebut bagi warga belajar, keluarga, masyarakat, dan bangsanya. Mereka juga mengetahui apakah warga belajar dapat merasakan bahwa materi tersebut mendukung terhadap nilai-nilai kehidupannya baik kehidupan sosial maupun kehidupan ekonomi.

Jika semua itu dapat diketahui dengan baik, mereka adalah guru pendidikan nonformal atau dikenal dengan tutor/fasilitator (tenaga pendidik pendidikan nonformal). Oleh karena itu, pengembangan kurikulum pendidikan nonformal harus betul-betul memperhatikan dan mengaktifkan semua komponen yang berhubungan dengan kelangsungan program pendidikan nonformal, atau tidak hanya sekadar mempartisipasikan warga belajar dalam proses pembelajaran saja.

Berdasarkan pertanyaan dan pernyataan tersebut, tutor dan fasilitator pendidikan nonformal memiliki tugas mendasar dalam mengembangkan kemampuan, keterampilan dan sikap warga belajar yang dapat mendukung kemandirian. Oleh karena itu, kompetensi yang harus dimiliki tutor dan fasilitator adalah :

1. terampil dan profesional dalam mengelola program pendidikan nonformal, baik program secara keseluruhan maupun program pembelajaran,

2. terampil dan profesional dalam membaca kebutuhan warga belajar/sasaran pendidikan nonformal,

3. terampil dan profesional dalam menyiapkan dan menerjemahkan kurikulum dan materi-materi kurikulum yang dapat membangun kemandirian,

4. terampil dan profesional dalam membaca masalahmasalah warga belajar dan masyarakat,

5. terampil dan profesional dalam melihat peluangpeluang baik peluang sosial maupun peluang ekonomi untuk pengembangan program,

6. terampil dan profesional dalam menjual program pendidikan nonformal (melakukan kemitraan), dan
7) terampil dan profesional dalam menggali sumbersumber yang dapat meningkatkan keunggulan program (daya saing) dan kelangsungan program.

\section{Kompetensi Tenaga Pendidik Pendidikan Nonformal dalam Meningkatkan Kemitraan Hidup Masyarakat}

Pendidikan nonformal sebagai bagian dari sistem pendidikan memiliki tugas yang sama dengan pendidikan formal yakni memberikan pelayanan terbaik terhadap masyarakat terutama masyarakat sasaran pendidikan nonformal. Sasaran pendidikan nonformal yang semakin luas yang tidak hanya sekadar berhubungan dengan masyarakat miskin dan bodoh (terbelakang, buta pendidikan dasar, drop out pendidikan formal), akan tetapi sasaran pendidikan nonformal terus meluas maju sesuai dengan perkembangan ilmu pengetahuan dan teknologi serta perkembangan lapangan kerja dan budaya masyarakat itu sendiri.

Mengingat sasaran pendidikan nonformal terus meluas, program/kegiatan pendidikan nonformal perlu terus diperluas sesuai dengan kebutuhan dan kondisi perkembangan masyarakat. Pada prinsipnya, perluasan kegiatan/program pendidikan nonformal hendaknya sejalan dengan pemikiran baru tentang konsep belajar (learning), dan belajar yang terkesan hanya berlangsung di sekolah (formal) sudah kurang tepat dan mulai bergeser ke luar setting persekolahan. Perubahan, pengembangan, dan perluasan pendidikan nonformal memberikan suatu apresiasi dan nuansa baru bagi tenaga pendidik pendidikan nonformal dalam menyediakan pendidikan bagi masyarakat, terutama orang dewasa, baik bagi mereka yang tidak memiliki akses kepada pendidikan formal maupun mereka yang pendidikan formalnya terbukti tidak memadai dan tidak relevan dengan kehidupan dan situasi yang berkembang di lingkungannya (masyarakat).

Proses pembangunan menuntut partisipasi jutaan orang dewasa yang terdidik, sementara lembaga pendidikan formal tidak mampu mengakses permasalahan-permasalahan pendidikan di tengahtengah masyarakat. Di daerah-daerah tertentu sejumlah penduduk menemukan bahwa sistem pendidikan persekolahan tidak mampu membekali keterampilanketerampilan yang mereka butuhkan untuk bersaing secara terbuka dan gamblang dalam masyarakat teknologis (Srinivasan, 1977).

Munculnya konsep masyarakat gemar belajar sepanjang hayat sebagai konsep utama, mendorong individu, lembaga, asosiasi, dan masyarakat peduli pendidikan atau badan usaha lain untuk ikut berpartisipasi dalam mengembangkan cara berpikir baru dalam merespon tantangan kebutuhan baru 
masyarakat tentang pendidikan dan belajar. Sekolah sebagai program formal tidak lagi menjadi satu-satunya wadah (wadah tunggal) dan memonopoli pendidikan formal (persekolahan) dan badan-badan bisnis tidak lagi mengurusi bisnis semata, akan tetapi sudah mulai bergeser ikut serta mengurusi pendidikan khususnya, pendidikan nonformal. Lahirnya organisasi-organisasi baru berpenampilan pendidikan dan lembaga-lembaga pendidikan tanpa label sebagai tambahan, perluasan lanjutan dan lainnya memberi kesempatan dan kemudahan kepada tenaga pendidik pendidikan nonformal bersama masyarakat untuk belajar membelajarkan diri, atau bersama-sama mengembangkan pendidikan nonformal.

Peran masyarakat yang dapat dijadikan contoh dalam membangun kemandirian warga belajar di antaranya adalah : masyarakat ikut mengembangkan dan membina Pusat Kegiatan Belajar Masyarakat (PKBM), sanggar-sanggar kegiatan belajar lain, magang, atau Kelompok Belajar Usaha (KBU) produktif, dan pesantren memberikan bekal bukan hanya dari segi agama, akan tetapi juga membangun berbagai prinsip yang dapat menumbuhkan kemandirian terutama kemandirian dalam hal berwirausaha sebagai bekal hidup dan kehidupannya di masyarakat. Sosialisasi usaha pendidikan secara luas melalui organisasi masyarakat dalam dunia pendidikan dikenal juga dengan sebutan masyarakat belajar (learning society). Begitu pula bekal-bekal pendidikan dan keterampilan yang berhubungan dengan mata pencaharian lainnya misalnya pertanian, perikanan, dan industri rumah tangga yang kesemua itu dibangun atas dasar swadaya, gotong-royong dan partisipasi. Hal-hal itulah kiranya yang dapat dijadikan contoh dan teladan dalam rangka mengembangkan perilaku mandiri dalam diri warga belajar.

Terciptanya masyarakat gemar belajar memberikan nuansa baru dan roh pendidikan di tengahtengah masyarakat. Kondisi ini dicermati sebagai suatu wujud nyata model pendidikan sepanjang hayat. Iklim tersebut mendorong terbukanya kesempatan setiap orang, organisasi dan institusi sosial, industri dan masyarakat untuk belajar lebih luas. Tumbuhnya semangat dan motivasi untuk belajar mandiri untuk memenuhi kebutuhan sepanjang hayat, dan memperkuat keberdaya-didikan (educability) masyarakat agar selalu mendidik diri dan masyarakat di lingkungannya adalah merupakan sisi positif dari lahirnya konsep-konsep yang mendasari pendidikan nonformal

Terciptanya masyarakat gemar belajar dapat menciptakan berbagai peluang bagi tenaga pendidik pendidikan nonformal untuk mampu menyelenggarakan pendidikan nonformal di tempat yang mudah dijangkau dengan cara-cara yang sesuai dengan potensi, kebutuhan, keterampilan dan kecakapan warga belajar. Dengan meta konsep seperti itu (educability), memungkinkan tenaga pendidik pendidikan nonformal bersama masyarakat dan warga belajarnya lebih giat mencari informasi baru yang berkaitan dengan pengembangan diri, masyarakat, dan kelompok belajarnya dalam rangka mendukung kepentingan hidupnya. Dalam keadaan melebarnya pelaksanaan pendidikan nonformal seperti itu, searahnya kondisi dan konsep belajar pendidikan nonformal, serta untuk menjaga mutu dan sensitivitas pendidikan nonformal di tengah-tengah masyarakat, ada lima strategi dasar yang perlu dikembangkan0dan dimiliki oleh tenaga pendidik pendidikan nonformal. Kelima analisis dasar itu ialah (1) pendekatan kemanusiaan (humanistic approach), masyarakat dipandang sebagai subjek pembangunan dan masyarakat diakui memiliki potensi untuk berkembang dan sedemikian rupa ditumbuhkan agar mampu membangun dirinya, (2) pendekatan partisipatif (participatory approach), mengandung arti bahwa masyarakat, lembaga-lembaga terkait, dan atau komunitas dilibatkan dalam pengelolaan dan pelaksanaan pembangunan masyarakat, (3) pendekatan kolaboratif (collaborative approach), dalam pembangunan masyarakat perlu adanya kerja sama dengan pihak lain (terintegrasi) dan terkoordinasi dan sinergi, (4) pendekatan berkelanjutan (continuation approach) pembangunan masyarakat dilakukan secara berkesinambungan, dan untuk itulah pembinaan kader yang berasal dari masyarakat menjadi hal yang paling pokok, (5) Pendekatan budaya (cultural approach) penghargaan budaya dan kebiasaan, adat istiadat yang tumbuh di tengah-tengah masyarakat dalam pembangunan masyarakat adalah hal yang perlu diperhatikan (Djudju Sudjana, 2000).

Dengan kelima kemampuan pendidikan tersebut, tenaga pendidik pendidikan nonformal akan mudah menganalisis, mengembangkan, dan melaksanakan program-program pendidikan nonformal yang sesuai serta dibutuhkan warga belajar/masyarakat. Artinya, program pendidikan nonformal yang dilaksanakan menyentuh dan mengangkat warga belajar/masyarakat menjadi lebih baik dalam kehidupannya yang ditandai dengan meningkatnya pendapatan (ekonomi), kesadaran akan lingkungan sosialnya, atau warga belajar/masyarakat yang mengerti dan memahami bagaimana membangun dirinya.

\section{Kompetensi yang Perlu Dimiliki Tenaga Pendidik Pendidikan Nonformal dalam Membangun Kemandirian Warga Belajar}


Dari penjabaran tentang kemandirian warga belajar di atas, kemandirian dalam pendidikan nonformal memberi acuan bagaimana warga belajar memiliki inisiatif untuk belajar, menganalisis kebutuhan belajar sendiri, mencari sumber belajar sendiri, memformulasi tujuan belajar sendiri, memilih dan mengimplementasikan strategi belajar dan melakukan evaluasi diri (self evaluation). Dalam upaya membangun kemandirian warga belajar pendidikan nonformal, tenaga pendidik pendidikan nonformal perlu memiliki serangkaian kompetensi yang antara lain adalah sebagai berikut.

1. Kompeten dalam mengarahkan program kegiatan pembelajaran yang berpusat pada warga belajar.

Program pendidikan nonformal dalam konsep pengembangan program pembelajarannya seringkali disusun dan dilakukan bersama-sama antara sumber belajar dan warga belajar sampai tahap evaluasi. $\mathrm{Di}$ samping itu, dalam konsep pembelajaran pendidikan nonformal, warga belajar diberikan kewenangan untuk menyusun, melaksanakan program pembelajaran, serta melakukan evaluasi pada program tersebut secara mandiri. Prinsip dasar yang dijadikan pegangan adalah mengacu pada konsep "dari, oleh, dan untuk warga belajar". Adapun tenaga pendidik pendidikan nonformal bertindak sebagai orang yang memberikan

bimbingan, dorongan atau arahan bila diperlukan. Konsep tersebut senada dengan apa yang diungkapkan Sudjana (1989:138), Knowles (1975) dan Jarvis (1992:130) bahwa warga belajar menyusun program atas dasar aktivitas dan kemampuan mereka sendiri dengan modal pengetahuan, keterampilan, serta sumber yang ada dan dapat mereka gunakan.

Teori pendidikan modern memandang bahwa warga belajarlah yang harus dijadikan subjek dan objek dalam proses pembelajaran. Rogers, mengistilahkannya dengan "student centered atau learner centered" atau disebut dengan kegiatan pembelajaran yang "terpusat pada warga belajar". Kegiatan belajar sebenarnya merupakan proses kegiatan ego dari warga belajar (Knowles, 1980:45). Kondisi seperti ini memberikan pengaruh yang signifikan terhadap keberhasilan warga belajar, baik keberhasilan dalam pencapaian tujuan pembelajaran maupun keberhasilan proses pembelajaran. Hal tersebut diakibatkan oleh adanya perubahan atau peningkatan dalam nalar, pengetahuan, keterampilan, dan sikap warga belajar. Dengan asumsi tersebut di atas warga belajar akan terampil dan mudah memahami, menguasai materi yang diberikan karena mendapat pengetahuan secara langsung dari kehidupan nyata.

Untuk itulah penyusunan program pendidikan nonformal harus atas dasar aktivitas warga belajar sendiri sehingga menjadikan warga belajar "belajar sambil bekerja" (learning by doing atau training by doing). Makna yang dapat diambil dari konsep tersebut, warga belajar benar-benar dapat menghayati proses berlangsungnya peristiwa yang dipelajarinya. Oleh karena warga belajar mengerjakannya sendiri, mereka akan mudah menguasai apa yang dipelajarinya. Materi yang dipelajarinya akan memberikan makna sangat mendasar bagi warga belajar (Butler, 1987).

Program pendidikan nonformal disusun atas dasar aktivitas warga belajar sendiri bukan berarti mau membantu warga belajar dalam mengembangkan kemampuannya. Akan tetapi, justru hal tersebut sesuai dengan tugas tenaga pendidik, yaitu membantu warga belajar dalam perkembangannya sendiri dan dapat membantu dirinya sendiri. Oleh karena dalam diri warga belajar terdapat dorongan alamiah untuk berkreasi dan untuk berkembang sendiri.

Untuk meningkatkan kreativitas, inisiatif dan prakarsa, intensitas program pembelajaran pendidikan nonformal hendaknya diupayakan lebih meningkat dari hari ke hari sehingga terjadi proses membudaya. Hal ini dilakukan dengan tujuan agar warga belajar terbiasa berjuang dalam meningkatkan kualitas dan taraf hidupnya dan tidak selalu menunggu pertolongan orang lain atau prinsip membangun diri (Connors, 1968).

Ada beberapa cara dalam meningkatkan kreativitas warga belajar dalam program pendidikan nonformal di antaranya adalah:

a. menghadapkan warga belajar dengan berbagai permasalahan yang dialami atau dihadapi dalam kehidupannya sehari-hari,

b. mendorong warga belajar untuk selalu meneliti dan selalu ingin tahu apa-apa yang dianggap baru oleh mereka,

c. mendorong dan memberi peluang warga belajar untuk selalu terjadi dialog, diskusi dalam kelompoknya atau dalam penyusunan suatu program pembelajaran, dan

d. tenaga pendidik bersama-sama warga belajar diupayakan memeriksa kembali apa yang telah dikerjakannya. 
Beberapa prinsip dalam penyusunan program pendidikan nonformal yang harus selalu diperhatikan tenaga pendidik pendidikan nonformal adalah sebagai berikut.

a. Kebutuhan (need) (Burton \& Meril, 1991). Prinsip dasar yang pertama ini, maksudnya adalah memberi kejelasan kepada warga belajar agar memahami dan mengerti pengetahuan dan keterampilan apa yang mereka ingin peroleh dari sebuah kegiatan pendidikan nonformal. Untuk kepentingan ini, warga belajar sebaiknya mematangkan terlebih dahulu berbagai keinginan, harapan melalui diskusi, dialog bersama tutor (sumber belajar) dan sesama warga belajar, serta pihak luar yang mengerti tentang pengembangan program yang akan dilaksanakan.

b. Sasaran. Prinsip dasar yang kedua adalah sasaran, maksudnya dalam setiap pengembangan program pendidikan nonformal harus sudah jelas sasaran yang akan dituju. Atau dalam rangka apa pengetahuan dan keterampilan yang mereka butuhkan itu. Apakah yang warga belajar butuhkan cocok dengan kondisi sasarannya. Misalnya, apakah dengan memiliki pengetahuan dan keterampilan dasar merajut atau membordir, warga belajar sudah dapat hidup dalam masyarakat luas dan keterampilan tersebut bisa diandalkan untuk bersaing dan laku di pasaran.

c. Sumber belajar (Resources). Prinsip yang ketiga adalah sebagai pendukung kegiatan program, baik sebagai pendukung proses pembelajaran maupun pendukung bagi terlaksananya seluruh kegiatan dari program pendididikan nonformal. Sumber-sumber tersebut biasanya berupa, dana (uang yang dibutuhkan), sumber belajar (fasilitator, instruktur, tutor dan lain-lain), fasilitas dan peralatan lain yang dibutuhkan baik perangkat keras (hardware) maupun perangkat lunak (software).

d. Hambatan. Hambatan ini biasanya timbul dari warga belajar maupun dari sumber belajar, atau dari sarana dan prasarana yang tidak memadai. Oleh karena itu, hambatan ini perlu diupayakan penanganannya sedini mungkin atau diprediksi ketika program pendidikan nonformal disusun. Di samping itu, setiap hambatan harus disusun berdasarkan pada jenis dan tingkat kesulitannya. Hal ini dilakukan dalam rangka penanganannya.

e. Alternatif. Prinsip yang terakhir ini maksudnya adalah setiap pengembangan program pendidikan nonformal hendaknya memberikan pilihan yang strategis terhadap semua alternatif dengan memperhitungkan sumber-sumber dan berbagai rintangan yang diketahui, dan sekaligus memahami sasaran yang hendak dicapai. Dalam setiap pemilihan alternatif sudah dinilai tentang untung rugi (cost benefit) dari masing-masing program. (Burton \& Meril, 1991, Kepner, \& Tregoe, 1975; Lunandi, 1980:47-57).

2. Kompeten dalam membangun kesesuaian isi program dengan sifat-sifat individualitas warga belajar

Dalam kerangka yang utuh, sebuah program pendidikan nonformal, isi dan jenis program yang dikembangkan (dalam bentuk dan satuan apapun), hendaknya selalu memperhatikan perkembangan pribadi warga belajar, baik perkembangan yang sedang terjadi, maupun perkembangan pada masa yang akan datang. Dengan demikian, dalam penentuan isi program pendidikan nonformal, kerangka isi materi perlu terlebih dahulu didiskusikan bersama warga belajar maupun bersama orang-orang yang berkepentingan dengan warga belajar.

3. Kompeten dalam memahami faktor keturunan (bakat dII) serta mengadaptasikannya denga isi program

Charon (1979:17) menyatakan bahwa faktor keturunan (hereditas) adalah berupa bakat atau pembawaan yang ada dalam diri warga belajar. Faktor tersebut turut mempengaruhi warga belajar dalam mengikuti suatu program pendidikan nonformal. Contoh yang bisa diambil dari pernyataan tersebut adalah warga belajar berbakat di bidang keterampilan tangan akan lebih tertarik dan lebih termotivasi mengikuti pembelajaran yang berhubungan dengan keterampilan merajut dan anyaman, daripada yang berhubungan dengan keterampilan menyanyi atau kesenian lainnya.

Pembawaan lain yang secara fitrah ada dalam diri manusia, bukan hanya berkaitan dengan unsur psikologis atau rohaniah, akan tetapi ada juga pembawaan yang bersifat biologis. Beberapa ahli menyebutkan antara lain Gouldner dan Poloma (1984: 418), Ki Hajar Dewantara (1977:441), H.C. Whiterington, (1985:61). Pembawaan psikologis dan biologis sebagai unsur dasar atau kodrat. Warga belajar yang berpenampilan sehat, segar bugar biasanya lebih lincah, riang gembira, berani, optimis, penuh semangat dalam mengikuti suatu program pembelajaran dibandingkan dengan warga belajar yang keadaan biologisnya lemah dan sering sakit. Oleh karena itu, faktor keturunan dalam diri warga belajar perlu mendapat perhatian terutama dalam proses pembelajaran dan dalam pengembangan isi program. $\mathrm{Hal}$ ini dimaksudkan agar warga belajar mampu 
mengembangkan bakat dan kemampuan bawaan yang dimilikinya secara sempurna. Sebaliknya, jika isi materi program kurang memperhatikan faktor tersebut, potensi yang dimiliki warga belajar menjadi tidak berkembang dengan lebih baik.

4. Kompeten dalam mengadaptasikan isi program dengan faktor lingkungan

Sudjana (2000:32) memberikan arahan yang jelas bagaimana keterkaitan antara komponen lingkungan sosial secara fungsional berkaitan dengan komponen-komponen lainnya dalam kerangka sistem pendidikan nonformal. Komponen-komponen lingkungan sosial antara lain adalah lingkungan keluarga, teman bergaul, teman bekerja, lapangan kerja, dan kelompok sosial. Adapun lingkungan lain yang juga perlu mendapat perhatian dalam pengembangan program pendidikan nonformal adalah lingkungan budaya dan lingkungan fisik. Lingkungan budaya bisa berupa adat istiadat, kebiasaan, norma, nilai-nilai, bahasa, atau hasil karya dan budi daya manusia. Adapun lingkungan fisik bisa berupa alam sekitar, termasuk temperatur, cuaca, iklim, dan lainlain. Lewin secara tegas menyatakan lingkungan memberikan pengalaman dalam mengembangkan kepribadian warga belajar. Oleh karena itu, keadaan lingkungan dan pengalaman warga belajar sangat berpengaruh terhadap aktivitas, motivasi dan tingkat kesuksesannya. (James W. Botskin, 1984:9, Selo Sumarjan, 1974:120 dan Nasution, 1988 :23).

Model materi program pendidikan nonformal yang dikembangkan mampu menyatu dengan keadaan dan tuntutan kebutuhan lingkungan serta pengalaman warga belajar, akan memberikan semangat dan akan mampu membangkitkan minat warga belajar. Hal lain yang dapat diperhatikan bahwa kondisi kesesuaian tersebut akan mempermudah warga belajar dalam menyerap dan memahami isi materi program yang dikembangkan. Kondisi tersebut sejalan dengan satuan pendidikan nonformal serta model-model program yang saat ini dikembangkan. Sebagai salah satu contoh, setiap hari masyarakat berhubungan dengan keterampilan (bordil, rajutan, anyaman, elektronik dan lain-lain.). Jika program kursus keterampilan dikembangkan di tengahtengah masa belajar dengan materi keterampilan yang cocok, masyarakat (warga belajar) yang mengikutinya akan dengan mudah dan cepat memahami dan terampil.

5. Kompeten dalam mengadaptasikan isi program dengan potensi diri warga belajar

Pendidikan nonformal dalam pengembangan programnya selalu mengacu pada asumsi potensi dan otonomi yang dimiliki warga belajar. Otonomi dan potensi tersebut merupakan bagian utama dalam setiap perencanaan dan pengembangan program pendidikan nonformal, terutama sebelum program digulirkan. Secara filosofis pandangan tersebut sejalan dengan konsep bahwa manusia memiliki potensi dan otonomi dalam kehidupannya. Pada konteks belajar, manusia sebagai makhluk otonom memiliki "kebebasan berkehendak", atau punya "free will", (learning and freedom) seperti yang dikemukakan oleh Max Weber (Don Martindale, 1970). Manusia tidak selalu tunduk begitu saja pada pengaruh dari pembawaan atau pengaruh lingkungannya. Manusia memiliki keinginan dan kehendak untuk menentukan nasibnya sendiri (selfdetermination). Artinya, manusia tidak selalu menggantungkan nasibnya pada keadaan yang ada, baik dalam dirinya maupun di luar dirinya. Oleh karena itu manusia wajib berusaha dan selalu optimis (M.Quraish Shihab; 2000: 226).

Nilai-nilai pedagogis yang ada dalam diri warga belajar merupakan keinginan yang sangat berharga. Atas dasar itu, keinginan yang tumbuh dalam diri warga belajar didorong oleh adanya motif intrinsik dalam mencapai suatu tujuan tertentu dalam hidupnya. Pada diri warga belajar akan berkembang perilaku yang selalu ingin berpacu, bersaing dalam belajar, tercipta dorongan ingin maju atau need for achievement (n'ach) (David C. McCleland, 1987). Dalam keadaan demikian tumbuh selalu rasa ingin tahu, suka berkompetisi, selalu ingin ambil peran, dan mau berbuat lebih dari batas kemampuan mental fisiknya. Ada kemampuan lain yang berpengaruh dalam diri warga belajar di antaranya adalah : (1) kesadaran (mind), (2) penyesuaian (adaptation), 3) imitasi (imitation), dan (4) identifikasi (identification). William Isac Thomas (1863-1917) dalam Martindale (1979:351) mengidentifikasi faktor-faktor biologis dan psikologis manusia menyebutkan bahwa manusia mempunyai seperangkat kemauan yaitu: 1) Pengalamam baru (new experience), 2) penghargaan (recognition), 3) penguasaan (mastery) dan, 4) keamanan (security).

Kecenderungan-kecenderungan tersebut harus mendapat perhatian yang nyata dalam setiap pengembangan materi program pendidikan nonformal, atau keinginan untuk mengubah nasib melalui kebebasan dalam belajar (autonomy) yang tumbuh dalam diri warga belajar.

7. Kompeten dalam mengembangkan isi program yang sesuai dengan perkembangan kehidupan warga belajar

Fase kehidupan manusia dalam perkembangannya tidak selalu linier. Pada fase-fase tertentu perkembangan kehidupan manusia kadang kala 
tenang, pada fase lain kadang kala mengalami kegoncangan dan krisis. Dewantara, (1977:311) menyatakan bahwa kehidupan manusia memiliki irama (rhythm), yakni harmoninya hubungan antara bagian yang satu dengan yang lain.

Merujuk pada hal itu, pengembangan isi program pendidikan nonformal memperhatikan kondisi yang terjadi dalam setiap fase kehidupan warga belajar. Hal tersebut perlu mendapat perhatian seksama tenaga pendidik pendidikan nonformal. Model program yang dikembangkan tanpa merujuk pada kondisi tersebut terutama pada pola kepribadian yang sebenarnya ada dalam diri warga belajar akan sulit mencapai keberhasilan. Dengan demikian, analisis setiap materi yang akan dikembangkan dan disampaikan kepada warga belajar harus merujuk pada kondisi perkembangan yang sedang dan akan terjadi pada diri warga belajar. Dengan demikian, kemampuan dan keterampilan melakukan analisis kebutuhan dan penelitian tindakan dalam kegiatan pembelajaran adalah salah satu bagian kompetensi yang harus dimiliki tenaga pendidik pendidikan nonformal.

8. Kompeten dalam mengadaptasikan makna belajar dengan pengembangan program.

Alfin Tofler dalam bukunya Future Shock (1992), menyatakan materi pembelajaran akan bermakna apabila bertujuan untuk meningkatkan kesadaran akan masa depan sehingga orang yang belajar terangsang untuk berpikir, berspekulasi dan mampu mengantisipasi peristiwa-peristiwa di masa yang akan datang. Begitu pula Nasution (1989:197-198) menyatakan bahwa materi yang bermakna bagi peserta didik adalah dihubungkan dan didasarkan atas pengalaman mereka dalam kehidupannya sehari-hari, seperti masalah kesehatan dan masalah lainnya dalam kehidupannya.

Asumsi-asumsi tersebut memberi batasan yang sangat kuat bagi pengambangan isi program pendidikan nonformal yang dikatakan bermakna dalam arti, setiap isi program pendidikan nonformal mempunyai makna bila mampu mengembangkan pola pikir positif-inovatif dan produktif bagi warga belajarnya. Dari materi tersebut, warga belajar mampu menyesuaikan diri dengan kehidupan yang dialaminya, warga belajar siap tanggap terhadap kehidupan masa kini dan masa depannya, serta terhadap masalahmasalah yang terjadi dalam lingkungannya. Oleh karena itu, setiap materi program yang akan dibangun dan dikembangkan selalu dipertanyakan makna yang terkandung di dalamnya, terutama makna bagi kehidupan dan penghidupan warga belajar serta lingkungannya.

\section{KESIMPULAN}

1. Menumbuhkan dan mengembangkan kemandirian warga belajar merupakan tujuan utama dalam pengembangan kurikulum dan pengembangan pembelajaran pendidikan nonformal. Kemampuan dan keterampilan tersebut merupakan bagian dari dimensi kompetensi yang dibutuhkan tenaga pendidik pendidikan nonformal dalam menyiapkan warga belajar menjadi manusia-manusia yang mandiri dan memiliki masa depan yang jelas. Untuk mendukung dimensi-dimensi itu, maka keterampilan yang harus dimiliki tenaga pendidik pendidikan nonformal adalah: (a) terampil dan professional dalam mengelola program pendidikan nonformal, baik program secara keseluruhan maupun program pembelajaran, (b) terampil dan professional dalam membaca kebutuhan warga belajar/sasaran pendidikan nonformal, (c) terampil dan professional dalam menyiapkan dan menerjemahkan kurikulum dan materi-materi kurikulum yang dapat membangun kemandirian, (d) terampil dan professional dalam membaca masalah-masalah warga belajar dan masyarakat, (e) terampil dan profesional dalam melihat peluang-peluang baik peluang sosial maupun peluang ekonomi untuk pengembangan program, (f) terampil dan professional dalam menjual program pendidikan nonformal (melakukan kemitraan), dan (g) terampil dan professional dalam menggali sumber-sumber yang dapat meningkatkan keunggulan program (daya saing) dan kelangsungan program.

2. Peran dan tugas tenaga pendidik pendidikan nonformal dalam membangun kemandirian warga belajar adalah sebagai berikut. (a) memahami dan mengembangkan kurikulum pembelajaran, (b) merencanakan dan menyiapkan bahan pembelajaran (materi). (c) memformulai proses pembelajaran. (d) mengelola administrasi pembelajaran. (e) mengelola proses pembelajaran. (f) memotivasi warga belajar. (g) menggali sumbersumber pembelajaran. $h$ ) mengaktifkan warga belajar dalam proses pembelajaran, dan (i ) mengevaluasi dan membuat laporan pembelajaran.

3. Untuk mendukung peran dan tugas maka dibutuhkan serangkaian kemampuan dan keterampilan tenaga pendidik pendidikan nonformal dalam menumbuhkan kemandirian yang sesuai dengan kondisi warga belajar sebagai berikut; (a) kompeten dalam mengarahkan kegiatan pembelajaran yang berpusat 


\section{DAFTAR PUSTAKA}

Botskin, J.W. (1984). No limits to learning: Bridging the human gap. Oxford: Pergamon Press.

Brembeck \& Thomson, T.J. (1973). New strategies for educational development. Toronto: Heath Company.

Connors, D.M. (1968). Strategies for development. Ottawa: Development Press.

Gouldner \& Poloma. (1973). For sociology. New York: Basic Books.

Jarvis, P. (1983). Professional education. London: Croom Helm, Ltd.,

Knowless, M.S. (1975). Self directed learning, a guide for learners and teachers. Chicago: Association Press and Follet Publishing Company.

Knowless, M.S. (1980). The modern practice of adult education, andragogy versus pedagogy. New York: Association Press.

Kominkan. (2006). History of education, establishment and operation of the Kominkan (Community cultural of Learning Centres).

Lewin, K. (1947). Feedback problems of social diagnosis and action. Human relation, United States : Longman.

Martindale, D. (1975). Handbook of contemporary development in world sociology. Greenwoo Press.

McCleland, D., dan Winter, D. (1969). Motivating economic achievement. New York: The Free
Press.

Nasution, S. (1989). Kurikulum dan pengajaran. Jakarta: PT Bina Aksara.

Sagir, S. (1986). Pendidikan luar sekolah dan Entrepreneurship. Bandung: PLS,IKIP.

Sagir, S. (1992). Peran pendidikan nonformal dalam meningkatkan keterampilan tenaga kerja. Bandung: PLS, IKIP.

Shihab, Q. (2000). Secercah cahaya ilahi. Bandung: Mizan.

Soemanto, W. (1976). Sekuncup ide operasional pendidikan wiraswasta. Jakarta: Bina Aksara.

Srinivasan, L. (1990). Tools for community participation. New York: PROWWSS/UNDP.

Sudjana, D. (2000). Pendidikan luar sekolah, wawasan sejarah perkembangan falsafah dan teori pendukung asas. Bandung: Nusantara Press.

Toffler, H. \& Gibson, R. (1998). Rethinking the future. Jakarta: Gramedia.

UN. (1956). Social progress through community development. New York, United Nations.

Yusuf, Daoed. (1976). Ketenagakerjaan dan entrepreneurship, makalah, seminar, Jakarta Universitas Indonesia.

(2003) Undang-Undang, Republik Indonesia, No.20 Tahun 2003 tentang sistem pendidikan nasional.

www.oise.utoronto.ca/.../assignment1/1949 kominkan.html 